\title{
Assessment Of The Availability, Utilization And Management Of ICT Facilities In Teaching English Language In Secondary Schools In Kaduna State, Nigeria
}

\author{
Hanna Onyi Yusuf \\ Department of Educational Foundations and Curriculum, Faculty of Education, \\ Ahmadu Bello University, Samaru-Zaria, Nigeria. TEL:+2348033207255 \\ E-mail: hannayusuf@yahoo.com \\ Bashir Maina \\ Department of Educational Foundations and Curriculum, Faculty of Education, \\ Ahmadu Bello University, Samaru-Zaria, Nigeria. TEL:+2348038899836 \\ Michael Omotayo Dare \\ Department of Educational Foundations and Curriculum, Faculty of Education, \\ Ahmadu Bello University, Samaru-Zaria, Nigeria. TEL:+2348087913488
}

\author{
Doi:10.7575/aiac.alls.v.4n.1p.20 \\ URL: http://dx.doi.org/10.7575/aiac.alls.v.4n.1p.20
}

Received: 02/12/2012

Accepted: 06/01/2013

\begin{abstract}
The study investigated the availability, utilization and management of ICT facilities in teaching English language in secondary schools in Kaduna State, Nigeria. The study adopted a descriptive survey research design. A questionnaire titled "Availability, Utilization and Management of Information and Communication Technology in teaching English Language in Secondary Schools" (AUMICTSS) was used for data collection. Twenty randomly selected secondary schools from Kaduna metropolis were used for the study. A total of 100 teachers participated by responding to the items on the questionnaire. The data collected was analysed using frequencies and percentages. The findings of the study revealed that there is a dearth of ICT facilities in secondary schools in Kaduna as there are only very few of such facilities available in most of the schools visited. It also revealed that most teachers were not competent in the use of these facilities as the management of these facilities requires training and re-training. It was recommended as a matter of urgency that government should provide more ICT facilities in schools and ensure the provision of electricity in every secondary school for optimal utilization of these facilities. Teachers should equally be trained and re-trained regularly in the use and management of ICT facilities for effective English Language curriculum delivery.
\end{abstract}

Keywords: assessment, ICT, Nigeria

\section{Introduction/Background of the study}

ICT is an acronym that stands for Information and communications Technology. There is no universally accepted definition of ICT because the concepts, methods and applications involved in ICT are constantly evolving on an almost daily basis. ICT covers any product that will store, retrieve, manipulate, transmit or receive information electronically in a digital form. For example, personal computers, digital television, email, internet etc.

The field of education has been affected by ICTs, which have undoubtedly affected teaching and research. A great deal of research has proven the benefits of ICT in improving quality of education (Yusuf, 2012 Warschaur, 2000). As a result of this, developed nations have integrated ICT into their educational system. Ayodeji (2004) observed that there are developments in the Nigerian education sector which indicate some level of ICT application in secondary schools in Nigeria. They traced the introduction of computer education in secondary schools to 1988, when Nigerian government enacted a policy on computer education. The Federal Government of Nigeria in the National Policy on Education (2007) recognizes the prominent role of ICTs in the modern world and has integrated ICTs into education in Nigeria. To actualize this goal, the document states that government will provide basic infrastructure and training at the primary school. At the junior secondary school, computer education is made a pre-vocational elective and is a vocational elective at the senior secondary school.

The advent of Information and Communication technology in schools have resulted in the presence of computer hardware and software in the English language classroom. To harness the potentials of technology, teachers play a pivotal role in ensuring technology use in English language classroom. Hence there is a need to investigate the availability, utilization and management of these resources for effective curriculum delivery. 


\section{Review of Related Literature}

Information and Communication Technology (ICT) may be viewed in different ways. It could be viewed as a set of activities which is facilitated by electronic means. It could also mean the processing, transmission and display of information via electronic means. BECTA (2000) in its own definition defined ICT as techniques people use to share, distribute, gather information and to communicate through computers and computer networks. Yunus (2007) described ICT as a complex varied set of goods, applications and services used for producing, distributing, processing, transforming information (including) telecoms, TV and radio broadcasting, hardware and software, computer services and electronic media. Adeleke (2005) and Agba et al (2004) and Stevenson (1997) viewed ICT as a cluster of associated technologies defined by their functional usage in information access and communication. Information and Communication Technology are computer based tools used by people to work with information and communication processing for the needs of an organization. It covers computer hardware, software, the network and other digital devices like video, audio, camera and so on which convert information (text, sound, motion etc) into digital form (Muchleison, 1997). Information and communication Technology as tools within the school environment include use for school administration and management, teaching and learning of ICT related skills for enhancing the presentation of classroom work, teaching/learning tasks, teaching/learning intellectual, thinking and problem solving skills, stimulating creativity and imagination, for speech by teachers and students and as communication tool by teachers and students (Pennington, 1996 and Moore 1996).

A survey carried out by Adam (1993) and Adeleke (2005) revealed that only one school, out of ten has computer sets. It is worth noting that none of the ten schools has internet facility. Ayodeji (2004) reported in a study that most of our secondary schools do not have software for the computer to function. One of the secondary schools has five computers against a population of 900 and no internet software was installed. The facilities are grossly inadequate for any meaningful teaching or learning to take place. On teachers' competence, teachers in Nigerian secondary schools are not competent in basic computer operation and in the use of genetic software, although they have positive attitude towards the use of computer (Yusuf, 2012, Ayodeji 2004). This finding revealed the low level of ICT penetration in the Nigerian school system. This reveals the state of ICT in most of the Nigerian secondary schools.

ICT is also an important medium that provides the potential for purposeful and powerful use of on-line communication in language and writing classes (Warschauer, 2000). On the Internet for instance, English as a second language (ESL/EFL) teachers can reinforce students to use the target language in an authentic setting (Azikiwe, 1998; Moore, 1996; Mosquera, 2001). ICT can also be a useful tool for collaboration among ESL/EFL learners locally, nationally or globally. It can be used to acquire information from a large number of language resources for a variety of purposes (Daugherty \& Funke, 1998; Kern and Warschauer, 2000).

Teachers can not only access resources for their classes but also supply their own materials, knowledge and ideas for other teachers via the Internet. For example, they can create homepages for the purpose of their lessons and put their materials on-line. Muechleisen (1997) recommends ESL/EFL teachers to utilize the Internet in their classes for motivating students to use the English language outside the classroom and to make the language a part of their daily lives. Kern and Warschauer (2000) indicate that language learners with access to ICT can potentially communicate with native speakers of English all over the world. They can communicate either on a one-to-one or many-to-many basis anytime they like, from school, home or work. Therefore, it is not surprising that some ESL/EFL teachers have embraced ICT assisted language teaching (IALT) and have developed new ways of using the ICT with their students.

Pennington (1996) points out that an ICT-based learning environment can offer an instructional tool. Ryder and Graves (1997) also assert that the ICT is a dynamic medium, which provides teachers and students with immediate access to tools and resources. Similarly, ICT can provide a wealth of information to students that are not readily available in textbooks or lectures. Students can access information and resources simply by having a computer with an Internet connection. The information is usually presented in meaningful contexts to explore widely or specifically. In addition, the use of the ICT can be interactive and collaborative in nature. Through e-mail, conferencing tools and newsgroups, a virtual community of learners can exchange knowledge, ideas and perspectives on certain issues or topics. As a result, ICT can increase English language learners' motivation to learn the English language. An empirical study on the availability, utilization and management of ICT facilities in teaching English language in secondary schools has not been carried out in Kaduna. Therefore, this study seeks to investigate this. The present study seeks to investigate the availability, utilization and management of ICT facilities in secondary schools in Kaduna metropolis.

\section{Objective of the Study}

The objective of the study were;

1. To determine the availability of ICT facilities in teaching English language in Secondary Schools in Kaduna metropolis.

2. To ascertain the level of use of ICT facilities in teaching English language in in secondary schools in Kaduna metropolis.

3. To assess the management of ICT facilities in teaching English language in secondary schools in Kaduna metropolis.

\section{Research Questions}

For the purpose of this study, three research questions were raised: 
1. What are the available ICT facilities for teaching English language in secondary schools in Kaduna metropolis?

2. What is the level of use of ICT facilities in teaching English language in secondary schools in Kaduna metropolis?

3. How are teachers able to manage ICT facilities in teaching English language in secondary schools in Kaduna metropolis?

\section{Methodology}

The descriptive research design was used for this study. The population of the study consists of all the three hundred and eighty four basic schools and two thousand one hundred teachers teaching in such schools in Kaduna State. Kaduna metropolis was used for the study. Twenty randomly selected Secondary Schools in Kaduna metropolis were used for the study. A total of one hundred (100) teachers were involved in the study.

A structured questionnaire for teachers tagged "Availability, Utilization and Management of Information and Communication Technology in teaching English Language in Secondary Schools" (AUMICTSS) was used for data collection. The questionnaire contained the Biodata information and three other sections.

Section one addressed the issue of availability of ICT facilities in teaching English Language in secondary schools. Section two addressed the issue of level of use of ICT facilities in teaching English Language in Secondary Schools. Section three addressed the issue of management of ICT facilities in teaching English language in secondary schools.

The instrument was validated through a pilot test that was carried out in GSS Kurmi Marshi. The instrument was pilot tested using ten (10) teachers who were not part of the main study but had the same qualifications as those used in the main study. A test-re-test approach using Pearson Product Moment Correlation (PPMC) was used to establish the reliability. The reliability coefficient of the instrument was 0.88 . Data collected from the study were analyzed using descriptive statistics, frequency counts and simple percentages.

\section{Data Analysis and Discussion}

The table below shows that $88 \%$ of the teachers used for the study are below 50 years. $60 \%$ are male and $40 \%$ are female. $68 \%$ are NCE holders, and $22 \%$ are degree holders. $58 \%$ have between 1 and 10 years teaching experience while $32 \%$ have between 11 and 20 years teaching experience.

\begin{tabular}{|l|l|l|}
\hline Age Distribution & 40 and below & 60 \\
& $41-50$ & 28 \\
& 51 and above & 12 \\
\hline Gender & Male & 60 \\
& Female & 40 \\
\hline Educational qualification & NCE & 68 \\
& B.A/BSc/B.Ed/B.Sc Ed/B.A Ed./HND & 22 \\
& M.sc/M.A/M.Ed & 10 \\
\hline Years of Experience & $1-10$ & 58 \\
& $11-20$ & 32 \\
& $21-30$ & 8 \\
\hline
\end{tabular}

Research Question 1: What are the available ICT facilities for teaching English language in secondary schools in Kaduna metropolis. The result generated from the study is presented in Table 1 and 2.

Table 1. Means and Standard Deviation Scores of views of teachers on ICT facilities Available in teaching English Language in Secondary Schools in Kaduna metropolis

\begin{tabular}{|l|l|l|l|}
\hline S/N & ICT FACILITIES & MEAN & SD \\
\hline 1 & Internet & 1.34 & 0.439 \\
\hline 2 & Multimedia Projector & 1.86 & 0.431 \\
\hline 3 & e-mail & 1.22 & 0342 \\
\hline 4 & Interactive Radio & 1.22 & 0.342 \\
\hline 5 & Interactive Boards & 1.22 & 0.342 \\
\hline 6 & Teleconferencing & 1.35 & 0.448 \\
\hline 7 & Audio Tapes & 1.87 & 0.432 \\
\hline 8 & Computers & 1.22 & 0.342 \\
\hline 9 & Photocopiers & 1.15 & 0.230 \\
\hline 10 & Handset & 1.85 & 0.849 \\
\hline 11 & Printer & 1.89 & 0.431 \\
\hline 12 & Ipad & 1.22 & 0.342 \\
\hline 13 & DVD,VCD & 1.87 & 0.432 \\
\hline 14 & Television & 1.15 & 0.230 \\
\hline
\end{tabular}


Table 1 above shows that all the 14 items had mean scores below the cut-off point of 2.5 on a four-point likert scale.

This indicates that there is a dearth of ICT facilities in secondary schools in Kaduna metropolis.

Table 2. Availability of ICT Facilities in Schools

\begin{tabular}{|l|l|c|c|c|c|}
\hline SN & \multicolumn{1}{|c|}{ STATEMENTS } & $\begin{array}{c}\text { Strongly } \\
\text { Disagree }\end{array}$ & Disagree & $\begin{array}{c}\text { Agree } \\
\text { Strongly } \\
\text { Agree }\end{array}$ \\
\hline 1 & $\begin{array}{l}\text { There are enough computers in my schools } \\
\text { My school has Educational Software for } \\
\text { teaching }\end{array}$ & 73 & 17 & 6 & 2 \\
\hline 3. & $\begin{array}{l}\text { Our computers are connected to the } \\
\text { internet }\end{array}$ & 41 & 9 & 36 & 14 \\
\hline 4. & We have interactive Boards in our schools & 100 & 0 & 0 & 0 \\
\hline 5. & $\begin{array}{l}\text { There are Television set that we use for } \\
\text { teaching }\end{array}$ & 72 & 10 & 12 & 6 \\
\hline 6. & $\begin{array}{l}\text { We have enough printers } \\
\text { There are Photocopiers in my schools }\end{array}$ & 80 & 10 & 7 & 3 \\
\hline 8. & $\begin{array}{l}\text { Multimedia facilities are available for } \\
\text { teaching English }\end{array}$ & 88 & 15 & 13 & 2 \\
\hline 9. & We have Projectors in our schools & 81 & 8 & 5 & 0 \\
\hline 10. & $\begin{array}{l}\text { Presence of a virtual library or } \\
\text { e-library }\end{array}$ & 65 & 15 & 13 & 7 \\
\hline
\end{tabular}

Table 2: shows that all the teachers disagreed on the adequacy of the ICT facilities available in the teaching of English language in secondary schools in Kaduna metropolis. This indicates that ICT facilities are not readily available in schools. Teachers do not have enough computers, no interactive boards educational softwares or multimedia facilities. Projectors and e-libraries are available only in a few schools. The answer to research question 1 is that there are very few ICT facilities in the teaching of English language in secondary schools in Kaduna metropolis.

Research Question 2: What is the level of use of the ICT facilities in teaching English in secondary schools in Kaduna metropolis? The result generated from the study is presented in table 3 and 4.

Table 3. Means and Standard Deviation Scores of views of teachers' ICT facilities Utilization in teaching English language in Secondary Schools in Kaduna State.

\begin{tabular}{|l|l|l|l|}
\hline S/N & ICT FACILITIES & MEAN & SD \\
\hline 1 & Internet & 1.34 & 0.439 \\
\hline 2 & Multimedia Projector & 1.86 & 0.431 \\
\hline 3 & e-mail & 1.22 & 0342 \\
\hline 4 & Interactive Radio & 1.22 & 0.342 \\
\hline 5 & Teleconferencing & 1.35 & 0.448 \\
\hline 6 & Audio Tapes & 1.87 & 0.432 \\
\hline 7 & Computers & 1.22 & 0.342 \\
\hline 8 & Laptops & 1.22 & 0.342 \\
\hline 9 & Photocopiers & 1.15 & 0.230 \\
\hline 10 & Handset & 1.85 & 0.849 \\
\hline 11 & Printer & 1.89 & 0.431 \\
\hline 12 & Ipad & 1.22 & 0.342 \\
\hline 13 & DVDs/VCDs/CDs & 1.87 & 0.432 \\
\hline 14 & Television & 1.34 & 0.339 \\
\hline
\end{tabular}

Table 3 shows that all the 14 items had mean scores below the cut-off point of 2.5 on a four-point likert scale. This indicates that the level of utilization of ICT facilities in secondary schools in Kaduna State is very poor. Over all, most of the teachers were not regular ICT users. Infact, most of the teachers recorded non use of the few ICT facilities that were available in their schools. 
Table 4. Teachers' use of ICT facilities in teaching English Language

\begin{tabular}{|c|c|c|c|c|c|}
\hline $\mathrm{SN}$ & STATEMENTS & $\begin{array}{l}\text { Strongly } \\
\text { Disagree }\end{array}$ & Disagree & Agree & $\begin{array}{l}\text { Strongly } \\
\text { Agree }\end{array}$ \\
\hline 1 & I can boot the computer & 18 & 15 & 25 & 42 \\
\hline 2 & $\begin{array}{l}\text { I use the computer to teach my students English } \\
\text { Language }\end{array}$ & 54 & 31 & 7 & 8 \\
\hline 3 & $\begin{array}{l}\text { I use the computer to keep records of students' } \\
\text { scores in English language }\end{array}$ & 50 & 29 & 15 & 6 \\
\hline 4 & I use Microsoft Word to teach English Language & 45 & 48 & 7 & 0 \\
\hline 5 & $\begin{array}{l}\text { I use Power Point in Presenting my English } \\
\text { Language lesson. }\end{array}$ & 49 & 37 & 14 & 0 \\
\hline 6. & $\begin{array}{l}\text { I browse the Internet to get materials for } \\
\text { teaching English }\end{array}$ & 21 & 34 & 22 & 23 \\
\hline 7 & I have an e-mail address & 24 & 26 & 15 & 35 \\
\hline 8 & I can use a search engine such as Google & 14 & 21 & 28 & 37 \\
\hline 9 & $\begin{array}{l}\text { I use education software such as CAI for } \\
\text { teaching English }\end{array}$ & 43 & 48 & 4 & 5 \\
\hline 10. & I can use a scanner to copy images & 49 & 43 & 6 & 2 \\
\hline 11. & $\begin{array}{l}\text { I can operate a printer that is connected to the } \\
\text { computer }\end{array}$ & 38 & 41 & 7 & 14 \\
\hline 12. & I can set up a multimedia projector & 46 & 42 & 7 & 5 \\
\hline 13. & $\begin{array}{l}\text { I use audio and video CDs, DVDs in teaching } \\
\text { English language }\end{array}$ & 33 & 30 & 22 & 15 \\
\hline 14 & I require more ICT training & 5 & 8 & 46 & 41 \\
\hline 15 & $\begin{array}{l}\text { ICT will enhance and build my confidence in } \\
\text { using ICT facilities in the classroom }\end{array}$ & 6 & 4 & 47 & 43 \\
\hline
\end{tabular}

Table 4 shows that all the teachers disagreed on the level of utilization of ICT facilities in teaching English language in secondary schools in Kaduna metropolis. The table shows that $67 \%$ can boot the computer, $15 \%$ use the computer to teach students English language, 7\% use Microsoft word to teach English, 14\% use power-point, 45\% browse the internet to get materials for teaching English language, 50\% have email addresses, $65 \%$ can use search engines such as google, majority of the teachers do not use education softwares, scanner, printer, multimedia projector, audio, video and DVDs. Majority of the teacher $87 \%$ require more training in ICT.

The answer to the research question 2 is that the level of utilization of the few available ICT facilities in teaching English language in secondary schools in Kaduna metropolis is very poor.

Research Question 3: How are teachers able to manage ICT facilities in teaching English language in secondary schools in Kaduna metropolis? The responses generated from the study is presented in table 5.

Table 5. Management of ICT facilities in English Language classrooms

\begin{tabular}{|l|l|c|c|c|c|}
\hline SN & \multicolumn{1}{|c|}{ STATEMENTS } & $\begin{array}{c}\text { Strongly } \\
\text { Disagree }\end{array}$ & Disagree & $\begin{array}{c}\text { Agree } \\
\text { Strongly } \\
\text { Agree }\end{array}$ \\
\hline 1 & $\begin{array}{l}\text { I know how to manage the ICT facilities in } \\
\text { my English language classroom }\end{array}$ & 72 & 10 & 8 & 10 \\
\hline 2. & $\begin{array}{l}\text { I know how to technically operate the ICT } \\
\text { assisted English language programmes for } \\
\text { teaching. }\end{array}$ & 18 & 12 & 50 & 20 \\
\hline 3. & $\begin{array}{l}\text { I require technical assistance in operating } \\
\text { the ICT facilities in my English language } \\
\text { classroom }\end{array}$ & 15 & 10 & 25 & 50 \\
\hline 4. & $\begin{array}{l}\text { Students will be more attentive in ICT } \\
\text { assisted English language teaching classes }\end{array}$ & 15 & 15 & 22 & 43 \\
\hline
\end{tabular}




\begin{tabular}{|l|l|c|c|c|c|}
\hline 5. & $\begin{array}{l}\text { I am responsible for the success of ICT } \\
\text { resources in teaching English language }\end{array}$ & 21 & 19 & 35 & 25 \\
\hline 6. & $\begin{array}{l}\text { I am competent to use ICT materials in the } \\
\text { classroom }\end{array}$ & 13 & 7 & 63 & 17 \\
\hline 7. & $\begin{array}{l}\text { I know how to integrate ICT resources into } \\
\text { existing English language curriculum }\end{array}$ & 28 & 12 & 39 & 21 \\
\hline 8. & $\begin{array}{l}\text { I need training to improve my ICT literacy } \\
\text { skills }\end{array}$ & 6 & 2 & 48 & 48 \\
\hline 9. & $\begin{array}{l}\text { I would like to use ICT materials and } \\
\text { activities in my English classroom as much } \\
\text { as possible }\end{array}$ & 7 & 3 & 42 & 54 \\
\hline 10. & $\begin{array}{l}\text { My ICT literacy skill is poor } \\
\text { Training in ICT will enhance and build my } \\
\text { knowledge and confidence in using ICT } \\
\text { facilities in the classroom }\end{array}$ & 10 & 8 & 33 & 49 \\
\hline
\end{tabular}

Table 5 above shows that $78 \%$ of the teachers considered their ICT training to be at a poor level. This is reflected in the responses that they made by strongly agreeing with the statement that their ICT training is at a poor level. $12 \%$ disagreed with the statement which means their ICT training maybe average, or below par. 24\% characterized their ICT training as being average, moderate or satisfactory. The remaining $10 \%$ strongly disagreed with the statement about their ICT training being at a poor level which means it is good, ok, excellent, or very good.

When enquired whether they would benefit from more training, almost all teachers (92\%) saw the significance of training by strongly agreeing with the statement that they require more ICT training skills. 8\% disagreed with the statement probably because they have already acquired some ICT training.

The answer to research questions 3 is that teachers indicated difficulties in using ICT facilities such as technical operations, slow internet connection or disconnection, finding appropriate teaching materials, and integrating internet resources, and taking much time to prepare and arrange ICT facilities in the classroom. Teachers also complained about constant electricity power failure. Some schools have no electricity supply for days or weeks. Some schools have no source of electricity at all.

\section{Discussion of Findings}

The result of this study shows that ICT facilities are not readily available in the schools covered by this study. It also shows that most of the schools are not connected to the internet. Schools with computers do not have the relevant educational software required by their students. In addition, the computers available in these few schools cannot meet the need of the large population of students in these schools. Some schools with internet connectivity have been cut off because they have not been able to pay their access fees and there is no regular electricity power supply. The findings of this study are in line with that of Adeleke (2005) Azikiwe (1998) and Stevenson (1997) that most schools in Nigeria are ill equipped for the application of ICT.

The study also showed that most teachers in secondary do not use ICT in teaching English language. The study further revealed that most of these teachers lack the knowledge and competence to use ICT facilities in teaching English language. This can be attributed to non availability of ICT facilities. The non availability of these facilities greatly hinders access and the inadequate training of teachers on the use and application of these facilities affects productivity.

\section{Conclusion}

The findings of the study have led to the conclusion that ICT facilities are not readily available in most secondary schools in Kaduna metropolis. The study revealed that most teachers do not use ICT facilities in teaching English language as teachers lack the basic skills to use the computer and other ICT devices.

This study has demonstrated that teachers have positive views on the use of the ICT for teaching English language while they have difficulties in finding appropriate teaching materials and in integrating ICT resources into the curriculum. The difficulties seem to be caused by the huge amount of information available on the internet for instance, and limited time to seek useful information. Another difficulty reported by the teachers is the organization and management of classes. When teachers use ICT facilities in the classroom, they need carefully selected ICT resources, they also need to address issues of managing class size, time and solving technical problems. To reduce the difficulties, teachers are required to develop ICT literacy and integration skills for themselves or through teacher training courses. If all English language teachers undertake well-planned training courses to gain and improve their ICT skills, English language instruction using ICT resources could be enhanced more actively, collaboratively and consistently across the school curriculum. It is also suggested that schools should be provided with modern, functional computer facilities and assisted by technical support. Although few teachers reported that their schools have computers with Internet connections, they point out that these connections do not seem to be working in the classroom yet. That is, teachers need appropriate computer facilities with reliable Internet connection as well as technical support to implement and promote ICT facilities which can improve the teaching of English language in secondary schools. 
- $\quad$ For the effective implementation of ICT teachers need to be competent enough to use ICT-based materials in the classroom. As suggested by the teachers' responses to the questions of their competency in the use of ICT-based materials and their knowledge of the integration of ICT resources into existing curricular, in-service training courses for ICT should be offered to teachers who need to learn how to use ICT resources, how to create or select internetbased activities, how to plan internet-assisted lessons and how to integrate ICT resources into actual classroom teaching. Through such training, teachers would understand the pedagogical and technical aspects of ICT, and teachers would be able to engage in their professional development and, as a result, their interest and willingness to use ICTbased materials and activities in the classroom could be well responded and constructively put into practice.

- $\quad$ Government should provide more ICT facilities such as computers, internet facilities, laptops, projectors, interactive boards etc in secondary schools and ensure the provision of electricity in every secondary school for optimal utilization of these facilities.

- $\quad$ Teachers should encourage Interaction with other people using computer-mediated communication (CMC) tools such as e-mail, discussion groups or chatting tools. This could be socially meaningful. Without being conscious of it, students may no longer consider learning the English language as a required subject in schools. Instead, they may consider the English language as a means of communicating with people from all over the world.

- In using ICT, teachers can use different types of teaching methods on the basis of their students' interest or needs. The use of ICT facilities supports the shift from the traditional teacher-centred classroom to the learner-centred classroom that is a current pedagogical preference in ESL teaching.

\section{References}

Abah, H. (2013). Nigeria: 10 Million Children out of school. Daily Trust Online.Retrived 8 April 2013. Benchmark.

Adam M. (1993). Students' Perception of Teacher Effectiveness and their Class Work Examination Performance in Secondary Schools in Borno State, Nigeria. Unpublished M.Ed. Dissertation, University of Maiduguri, 128p.

Adeleke, A.A. (2005). Use of Library Resources by Academic Staff of the Nigerian Polytechnics, Journal of Library Science, 12(2) 15-24.

Agba, D.M., Kigongo-Bukenya, I.M.N and Nyemba, J.B (2004) Utilization of Electronic Information Resources by Academic Staff at Makerere Univesity. University of Dar-es-salam Library Journal, 6(1) 18-28.

Ayodeji, G.S (2004). Education and Development: A paper presented at a Training Workshop organized by Manpower Development Department, NISER, Ibadan.

Azikiwe, U. (1998). Language teaching and learning. Onitash: Africana-FEP Publishers Ltd.

Becta (2000) Primary Schools of the Future - Achieving Today. Coventry: Becta

Daugherty, M., \& Funke, B.L. (1998). University faculty and student perceptions of Web-based instruction. Journal of distance education.

Federal Government of Nigeria (2007) National Policy on Education Abuja: NERDC press.

Kern, R., \& Waschauer, M. (2000). Introduction: Theory and practice of network-based language teaching. In M. Warschauer \& R. Kern (Eds.), Network-based language teaching: Concept and practice (pp. 1 - 19). New York: Cambridge University Press.

Moore, P. (1996). Reading and writing on the Internet. The Australian journal of language and literacy, 16(4), 317-329.

Mosquera, F.M. (2001). CALT: Exploiting Internet resources and multimedia for TEFL in developing countries. Computer assisted language learning, 14(5), 461-468.

Muehleisen, V. (1997). Project using the Internet in college English classes. The internet TESL journal, $3(6), 1-7$.

Pennington, M.C. (1996). The power of the computer in language education. In M.C Pennington (Ed). The power of CALL (pp. 1-14). Houston: Athelstan.

Ryder, R.J., \& Graves, M.F. (1997). Using the Internet to enhance students' reading, writing, and information gathering skills. Journal of adolescent \& adult literacy, 4(4), 244-254.

Stevenson, D. (1997). Information and Communications Technology in UK Schools: An Independent Inquiry. London: Independent Inquiry. London: Independent ICT in schools Commission.

Warschauer, M. (2000). On-line learning in second classrooms. In M. Warschauer \& R. Kern (Eds.), Network-based language teaching: concepts and practice (pp.41-58). New York: Cambridge University Press.

Yunus Mohd, M. (2007). Malaysain ESL teachers' use of ICT in their classrooms: expectations and realities. ReCALL. 19(1): 79-95.

Yusuf H.O (2012). Fundamentals of Curriculum and Instruction. Kaduna: Joyce Publishers. 